\title{
DAMPAK KEGIATAN PERTANIAN TERHADAP TINGKAT EUTROFIKASI DAN JENIS - JENIS FITOPLANKTON DI DANAU BUYAN KABUPATEN BULELENG PROVINSI BALI
}

\author{
Ni Putu Vivin Nopiantari ${ }^{\left.1^{*}\right)}$, I Wayan Arthana ${ }^{2)}$ dan Ida Ayu Astarini ${ }^{3)}$ \\ ${ }^{1)}$ Program Studi Magister Ilmu Lingkungan Pesisir Universitas Udayana \\ ${ }^{2)}$ Fakultas Kelautan Dan Perikanan Universitas Udayana \\ ${ }^{3}$ Fakultas MIPA Universitas Udayana \\ "Email : vi2n.bali@gmail.com
}

\begin{abstract}
This research was conducted to find out the impact of agricultural activities in the various levels of eutrophication and diversity of phytoplankton in Buyan Lake, Buleleng, Bali Province. Purposive sampling method was organized to determining research station, where the sampling stations were determined based on various considerations, such as conditions of study area, and predominant use of agricultural land in the study area. Sampling method of phytoplankton and the lake water were done by setting the 4 stations that represent agricultural activities around Buyan Lake. Phytoplankton samples were taken by filtering the water on the lake surface as much as 100 liters, using the plankton net with a mesh size of $25 \mu \mathrm{m}$. Phytoplankton parameters was analyzed in laboratory. Data was analyzed using analysis of phytoplankton abundance, Equity index and dominance index. Results showed that abundance of phytoplankton at each stations in Buyan Lake was ranged between $1150-1791.67$ cells / l. Average abundance of phytoplankton in all stations was 1504.17 cells / l. Based on the abundance of phytoplankton, waters of Buyan Lake was classified into water that have low fertility rate (oligotrophic). Agricultural activities around Buyan Lake resulted a moderate eutrophication level (mesotrofik).
\end{abstract}

Keywords: Eutrophication, phytoplankton, Buyan Lake

\section{PENDAHULUAN}

Danau merupakan salah satu bentuk ekosistem air tawar yang bersifat menggenang (lentic). Ekosistem ini menempati daerah yang relatif tidak luas pada permukaan bumi dibandingkan dengan habitat laut dan daratan (Effendi, 2003). Danau Buyan adalah sebuah danau yang terletak di Desa Pancasari, Kecamatan Sukasada, Kabupaten Buleleng, Bali. Luas Danau Buyan 301.84 Ha ini merupakan satu dari tiga danau kembar yang terbentuk di dalam sebuah kaldera besar. Danau Buyan diapit oleh kedua danau lainnya, yakni Danau Tamblingan di sebelah barat dan Danau Beratan di sebelah timur. Kedalaman Danau Buyan diperkirakan sekitar 80 meter, dimana kedalaman danau ini pernah mencapai 140 meter sebelum terjadi pendangkalan dasar danau akibat erosi dan eutrofikasi.

Pemanfaatan pupuk anorganik untuk budidaya sayuran dan tanaman buah-buahan di sekitar Danau Buyan, diduga sudah melewati ambang batas baku mutu dan mengakibatkan meningkatnya pencemaran zat kimia. Pencemaran itu menyebabkan degradasi atau penurunan kualitas lingkungan. Hal itu terjadi disebabkan tingginya pemakaian pupuk kimia dan pestisida yang menyebabkan masuknya kandungan nitrat dan fosfat. Petani di sekitar Danau
Buyan yang dikenal sebagai sentra sayuran dan buah - buahan menggunakan pupuk anorganik untuk meningkatkan kualitas maupun kuantitas hasil panen. Namun penggunaan pupuk yang melebihi dosis diduga terus meningkatkan pencemaran perairan Danau Buyan.

Penyuburan perairan (eutrofikasi), termasuk yang terjadi di Danau Buyan ternyata sudah menjadi salah satu permasalahan yang rumit. Permasalahan eutrofikasi ini terkait dengan berbagai kegiatan aktivitas masyarakat di sekitar perairan. Penelitian ini bertujuan untuk mengidentifikasi dampak kegiatan pertanian terhadap tingkat eutrofikasi di perairan Danau Buyan, mengetahui struktur kumunitas fitoplankton sebagai bio indicator dan untuk mengetahui tingkat kesuburan perairan Danau Buyan dilihat dari kelimpahan fitoplankton.

\section{METODOLOGI}

Penentuan lokasi pengambilan sampel air menggunakan metode purposive sampling yaitu penentuan stasiun pengamatan dilakukan dengan memperhatikan berbagai pertimbangan dan kondisi daerah penelitian, serta kondisi dominan pemanfaatan lahan pertanian pada lokasi penelitian. Untuk itu ditentukan 4 stasiun yang mewakili 
kegiatan pertanian disekitar Danau Buyan. Pada masing - masing stasiun ditentukan 10 sub stasiun pengambilan sampel, sehingga ada 40 sub stasiun. Ke 10 sub stasiun pada masing - masing stasiun di komposit sehingga mendapatkan sampel yang homogen. Sampel Fitoplankton diambil dengan menyaring air permukaan sebanyak 100 liter menggunakan jaring plankton dengan ukuran mesh 25. Pengambilan sampel dilakukan pada bulan Februari 2014. Analisis kandungan bahan organik dalam sampel air dilakukan di UPT Balai Laboratorium Kesehatan Provinsi Bali. Analisis struktur komunitas fitoplankton dilaksanakan di UPT Laboratorium, Sumberdaya Genetika dan Biologi Molekuler Universitas Udayana Denpasar.

Untuk identifikasi dan menghitung kelimpahan fitoplankton berpedoman pada Yamaji (1976), dan Davis (1995). Sedangkan untuk perhitungan kelimpahan fitoplankton menggunakan rumus APHA (1989)

$$
\mathrm{N}=Z \quad X \frac{\mathrm{X}}{\mathrm{Y}} \times \frac{1}{\mathrm{~V}}
$$

Dimana :

$$
\begin{aligned}
\mathrm{N} & =\text { Kelimpahan individu fitoplankton (Individu/ } \\
& \text { liter) } \\
Z & =\text { Jumlah individu fitoplankton } \\
\mathrm{X} & =\text { Volume air sampel yang tersaring }(50 \mathrm{ml}) \\
\mathrm{Y} & =\text { Volume } 1 \text { tetes air }(0,06 \mathrm{ml}) \\
\mathrm{V} & =\text { Volume air yang disaring }(100 \mathrm{l})
\end{aligned}
$$

Indeks Keanekaragaman yang digunakan untuk menghitung indeks ini adalah persamaan SharonWiener (Michael, 1994).

$$
\mathrm{H}^{1}=-\sum_{i=1}^{n} p_{i} \ln p_{i}
$$

Dimana :

$\mathrm{H}^{1}=$ indeks Keanekaragaman

$\mathrm{Pi}=\mathrm{ni} / \mathrm{N}$

ni $=$ jumlah individu jenis ke I

$\mathrm{N}=$ jumlah total individu

$\mathrm{H}^{\prime}<1=$ komunitas biota tidak stabil atau kualitas air tercemar berat, $1<\mathrm{H}^{\prime}<3=$ stabilitas komunitas biota sedang atau kualitas air tercemar sedang, $\mathrm{H}^{\prime}>3$ = stabilitas komunitas biota dalam kondisi prima (stabil) atau kualitas air bersih.

Indeks Kesamaan menurut Michael (1994), Indeks ini menunjukkan pola sebaran biota yaitu merata atau tidak. Jika nilai indeks relatif tinggi maka keberadaan setiap jenis biota di perairan dalam kondisi merata.

$$
E=\frac{H}{H M a k s}
$$

Dimana :

E : Indeks kesamaan

H' maks : Ln s ( s adalah jumlah genus)

$\mathrm{H}$ : Indeks keanekaragaman

$\mathrm{E}=0-0.5$, pemerataan antar spesies rendah, artinya kekayaan individu yang dimiliki masing-masing spesies sangat jauh berbeda. $\mathrm{E}=0.6-1$, pemerataan antar spesies relatif seragam atau jumlah individu masing-masing spesies relatif sama.

Indeks dominansi menggambarkan komposisi jenis dalam komonitas jenis dalam komunitas dan spesies yang dominan dalam suatu komunitas memperlihatkan kekuatan spesies lain (Krebs, 1978). Indesk dominansi dapat dihitung menggunakan persamaan Indeks Dominansi Simpson (Odum, 1993) yaitu sebagai berikut:

$$
\mathrm{C}=\sum_{i=1}^{n}\left(n_{i} / N\right)^{2}
$$

$$
\begin{aligned}
& \text { Dimana: } \\
& \mathrm{C} \text { = Indeks dominansi Simpson } \\
& \text { ni }=\text { Jumlah individu jenis ke-i } \\
& \mathrm{N} \text { = Jumlah total individu } \\
& \mathrm{S} \text { = Jumlah genus }
\end{aligned}
$$

\section{HASIL DAN PEMBAHASAN}

Hasil pengamatan mikroskopis menunjukkan bahwa fitoplankton yang didapatkan di Danau Buyan sebanyak 30 spesies (Tabel 3) yang terdiri dari 6 Divisi, yaitu Bacillariophyta (7 genus), Chlorophyta (5 genus), Cyanophyta (3 genus), Chrysophyta (2 genus), Dinophyta (1 genus), Pyrrophycophyta (1 genus ), seperti yang terlihat pada Tabel 5.2. Jumlah spesies yang ditemukan pada setiap stasiun, yaitu stasiun 1 (18 spesies), stasiun 2 (10 spesies), stasiun 3 (15 spesies), dan stasiun 4 (20 spesies). Terdapat beberapa spesies yang selalu ditemukan pada keempat stasiun antara lain Bacillariophyta (3 spesies), Chlorophyta (3 spesies), dan Chrysophyta (1 spesies).

Komposisi (\%) Fitoplankton berdasarkan kelimpahan masing - masing Phyllum di Danau Buyan didominasi oleh Phyllum Bacillariophyta sebanyak 81,7\%. Selain phylum Bacillariophyta, terdapat beberapa phylum fitoplankton lain yang menyusun populasi plankton di Danau Buyan, seperti Chlorophyta $13,3 \%$, Cyanophyta $3,1 \%$, Chrysophyta 1,7\% dan Phyllum terendah 0,1\% yaitu Dinophyta dan Phyrophycophyta. Hal tersebut menunjukan phylum Bacillariophyta memiliki penyebaran yang luas di perairan Danau Buyan. (Gambar 1.).

Pengukuran kualitas air danau buyan dilakukan secara in situ pada parameter Suhu, DO dan $\mathrm{pH}$ sedangkan pengukuran laboratorium dilakukan pada 
Tabel 3. Jenis dan Kelimpahan rata - rata fitoplankton (ind//) yang ditemukan di Danau Buyan

\begin{tabular}{|c|c|c|c|c|c|c|}
\hline No & Nama Spesies & Stasiun 1 & Stasiun 2 & Stasiun 3 & Stasiun 4 & Rata-Rata \\
\hline & Bacillariophyta & & & & & \\
\hline 1 & Cerataulina bergonii & 16,67 & 25 & 8,33 & 16.67 & 12,5 \\
\hline 2 & Cymbella parva & 8,33 & 0 & 8,33 & & 4,17 \\
\hline 3 & Gomphonema sphaerophorum & 8,33 & 0 & 8,33 & 25 & 4,17 \\
\hline 4 & Navicula platystoma & 0 & 0 & 0 & 8,33 & 0 \\
\hline 5 & Navicula medisculus & 0 & 0 & 0 & 8,33 & 0 \\
\hline 6 & Navicula placentula & 0 & 0 & 0 & 8,33 & 0 \\
\hline 7 & Navicula pupula & 0 & 0 & 0 & 8,33 & 0 \\
\hline 8 & Rhizosolenia cylindrus & 8.33 & 0 & 16,67 & 33,33 & 6,25 \\
\hline 9 & Rhizosolenia stolterfothii & 50 & 16,67 & 25 & 25 & 22,92 \\
\hline 10 & Rhopaloidea gibba & 0 & 0 & 8,33 & & 2,83 \\
\hline \multirow[t]{3}{*}{11} & Synedra ulna & 1066,67 & 883,33 & 1491,67 & 1133,33 & 860,42 \\
\hline & Total & 1158,33 & 925 & 1566,66 & 1266,6 & 912,50 \\
\hline & Chlorophyta & & & & & \\
\hline$\overline{12}$ & Chlorococcum humicola & 75 & 41,67 & 50 & 58,33 & 56,25 \\
\hline 13 & Coelastrum cambricum & 8,33 & 0 & 0 & & 2,08 \\
\hline 14 & Golenkinia paucispinum & 8,33 & 0 & 0 & 8,33 & 4,17 \\
\hline 15 & Hyalotheca undulata & 8,33 & 0 & 8,33 & 33,33 & 12,50 \\
\hline 16 & Staurastrum anatinum & 0 & 0 & 0 & 8,33 & 2,08 \\
\hline 17 & Staurastrum bloklandiae & 8,33 & 8,33 & 8,33 & 16,67 & 10,42 \\
\hline 18 & Staurastrum johnsonii & 8,33 & & 16,67 & & 6,25 \\
\hline 19 & Staurastrum paradoxum & 66,67 & 108,33 & 108,33 & 125 & 102,08 \\
\hline \multirow[t]{3}{*}{20} & Ulothrix zonata & & & & 16,67 & 4,17 \\
\hline & Total & 183,32 & 158,33 & 191,66 & 266,66 & 199,99 \\
\hline & Cyanophyta & & & & & \\
\hline 21 & Gloeocapsa magma & 0 & 0 & 0 & 75 & 18,75 \\
\hline 22 & Oscillatoria limosa & 8,33 & 25 & 0 & 0 & 8,33 \\
\hline 23 & Nostoc linckia & 0 & 0 & 0 & 8,33 & 2,08 \\
\hline 24 & Nostoc planctonicum & 16,67 & 0 & 0 & 0 & 4,17 \\
\hline \multirow[t]{3}{*}{25} & Oscillatoria kawamurae & 8,33 & 0 & 0 & 41,67 & 12,5 \\
\hline & Total & 33,33 & 25 & 0 & 125 & 45,83 \\
\hline & Chrysophyta & & & & & \\
\hline 26 & Melosira stalica & 0 & 8,33 & 16,67 & 0 & 6,25 \\
\hline 27 & Navicula radiosa & 0 & 0 & 8,33 & 0 & 2,08 \\
\hline \multirow[t]{3}{*}{28} & Melosira granulata & 16,67 & 25 & 8,33 & 16,67 & 16,67 \\
\hline & Total & 16,67 & 33,33 & 33,33 & 16,67 & 25 \\
\hline & Dinophyta & & & & & \\
\hline \multirow[t]{3}{*}{29} & Diplopsalis lenticula & 0 & 8,33 & 0 & 0 & 2,08 \\
\hline & Total & 0 & 8,33 & 0 & 0 & 2,08 \\
\hline & Pyrrophycophyta & & & & & \\
\hline \multirow[t]{2}{*}{30} & Hypnodinium sphaericum & 8,33 & 0 & 0 & 0 & 2,08 \\
\hline & Total & 8,33 & 0 & 0 & 0 & 2,08 \\
\hline \multirow[t]{6}{*}{ No } & Nama Spesies & Stasiun 1 & Stasiun 2 & Stasiun 3 & Stasiun 4 & Rata-Rata \\
\hline & Total & 1400 & 1150 & 1791,67 & 1675 & 1504,17 \\
\hline & Jumlah spesies perstasiun & 18 & 10 & & 20 & 15.75 \\
\hline & Indeks Keanekaragaman $\left(\mathrm{H}^{\prime}\right)$ & 1.121 & 0.963 & 0.812 & 1.455 & 1.09 \\
\hline & Indeks kesamaan (E) & 0.414 & 0.463 & 0.326 & 0.662 & 0.47 \\
\hline & Indeks Dominansi ( $C$ ) & 0.587 & 0.601 & 0.698 & 0.469 & 0.59 \\
\hline
\end{tabular}

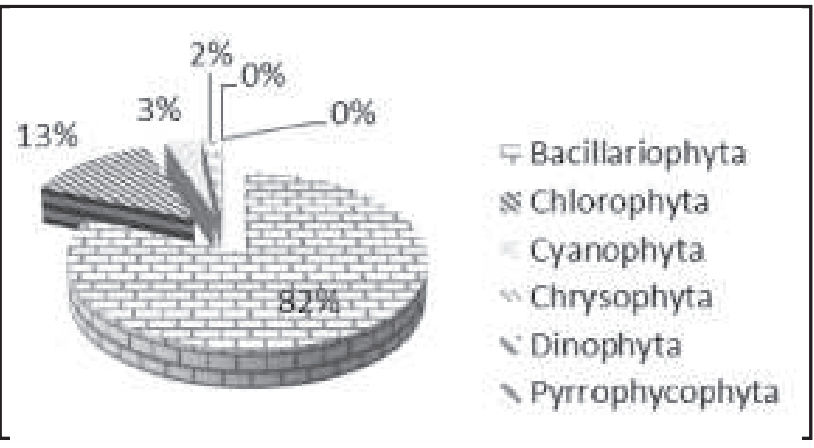

Gambar 1. Komposisi (\%) Fitoplankton berdasarkan kelimpahan masing - masing Phyllum di Danau Buyan parameter TDS, TSS, Amonia, Nitrit, Nitrat, BOD, COD dan Fosfat (Tabel4)

Pola hubungan kadar nitrat dan fosfat pada setiap stasiun pengambilan sampel. Pada stasiun 1 terlihat perbandingan nilai yang cukup tinggi dimana nilai nitrat di stasiun 1 , yaitu $5.545 \mathrm{mg} / \mathrm{l}$ dan fosfat di strasiun 1, yaitu $1.259 \mathrm{mg} / \mathrm{l}$. Pada stasiun 2 nilai nitrat juga lebih tinggi dari pada nilai fosfat dan menurun pada stasiun 3 dan 4 yaitu nilai fosfat lebih tinggi dari pada nitrat.(Gambar 2).

Pola hubungan nitrat dan fitoplankton di Danau Buyan dapat dilihat pada Gambar 4. Pola hubungan 
Tabel 4. Hasil Analisis Kualitas Air Danau Buyan

\begin{tabular}{|c|c|c|c|c|c|c|c|c|c|c|}
\hline \multirow[t]{2}{*}{ No } & \multirow[t]{2}{*}{ PARAMETER } & \multirow[t]{2}{*}{ METODE } & \multicolumn{4}{|c|}{ BAKU MUTU AIR* } & \multicolumn{4}{|c|}{$\begin{array}{l}\text { HASIL PEMERIKSAAN } \\
\text { (satuan mg/l) }\end{array}$} \\
\hline & & & 1 & II & III & IV & S.I & S.II & S.III & S.IV \\
\hline \multicolumn{3}{|c|}{ FISIKA } & & & & & & & & \\
\hline 1 & $\mathrm{SUHU}{ }^{\circ} \mathrm{C}$ & Suhu meter & - & - & - & - & 23,9 & 24,1 & 23,9 & 23,8 \\
\hline 2 & TSS & Spektrofotometri & 50 & 50 & 400 & 400 & 3 & 3 & 2 & 3 \\
\hline 3 & TDS & Elektometri & 1000 & 1000 & 1000 & 2000 & 125 & 131 & 130 & 131 \\
\hline \multicolumn{3}{|c|}{ KIMIA } & & & & & & & & \\
\hline 4 & DO & Do meter & 6 & 4 & 3 & 1 & 7,5 & 5,5 & 6 & 5 \\
\hline 5 & $\mathrm{pH}$ & Ph meter & $6-9$ & $6-9$ & $6-9$ & $5-9$ & 6,92 & 6,85 & 7,11 & 7,28 \\
\hline 6 & BOD & Titrimetri & 2 & 3 & 6 & 12 & 12,64 & 12,00 & 8,22 & 7,58 \\
\hline 7 & $\mathrm{COD}$ & Titrimetri & 10 & 25 & 50 & 100 & 49.80 & 19,92 & 9,96 & 199,2 \\
\hline 8 & AMMONIA & Nessler & 0,5 & - & - & - & 0.071 & 0,039 & 0,040 & 0,060 \\
\hline 9 & NITRIT & Sulfanilat & 0,06 & 0,06 & 0,06 & - & 0,004 & 0,004 & 0,003 & 0,003 \\
\hline 10 & NITRAT & Brucine & 10 & 10 & 20 & 20 & 5,545 & 1,805 & 1,010 & 0,895 \\
\hline 11 & FOSFAT & Amm-molybdat & 0,2 & 0,2 & 1 & 5 & 1,259 & $\begin{array}{l}1,171 \\
1\end{array}$ & $\begin{array}{l}1,185 \\
9\end{array}$ & 1,1760 \\
\hline
\end{tabular}

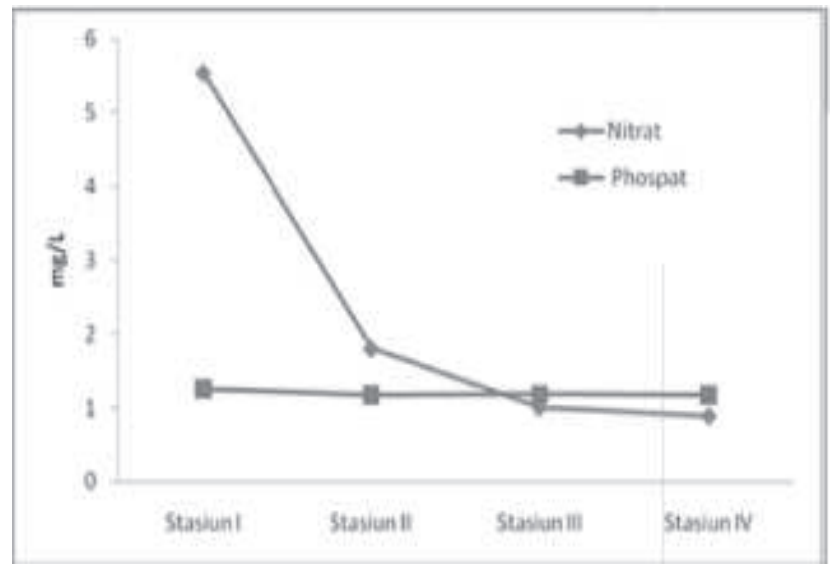

Gambar 2. Pola hubungan nitrat dan fosfat di Danau Buyan

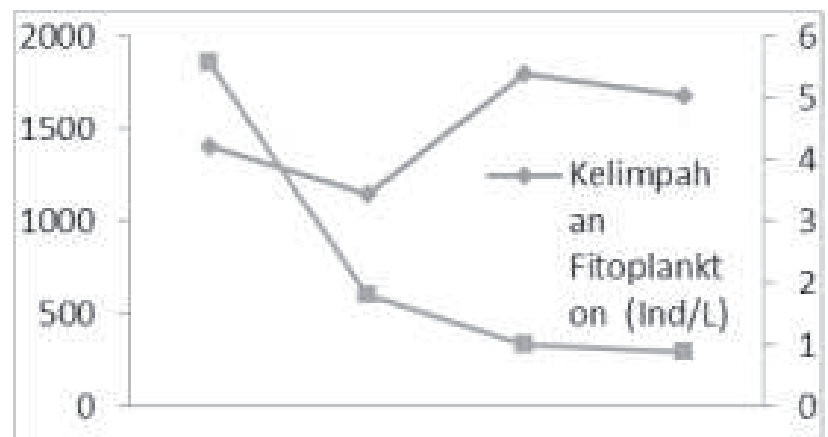

Stasiun I Stasiun II Stasiun III Stasiun IV Gambar 3. Pola hubungan nitrat dan fitoplankton

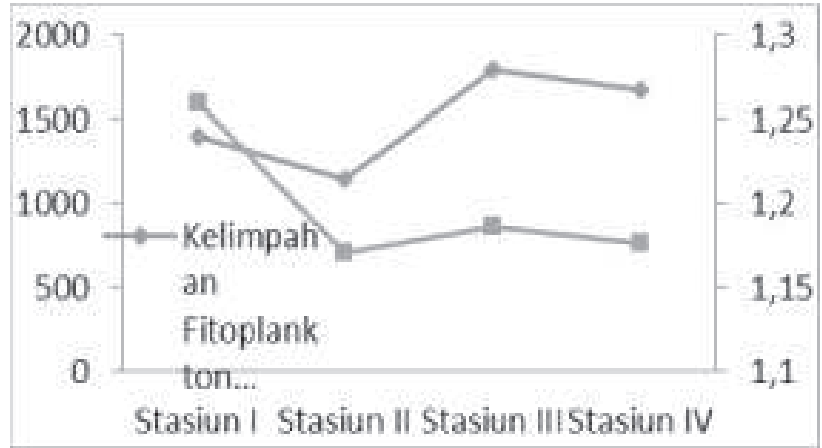

Gambar 4. Pola hubungan fosfat dan fitoplankton

nitrat di Danau Buyan memiliki kecenderungan berbanding terbalik pada stasiun 1 , stasiun 3 dan stasiun 3, yaitu ketika kadar nitrat menurun kelimpahan fitoplankton meningkat begitu juga sebaliknya. Ketika kadar nitrat meningkat kelimpahan fitoplankton menurun. Sedangkan di stasiun 2 pola hubungan nitrat dan fitoplankton menunjukan hubungan sejalan yaitu ketika kadar nitrat menurun kelimpahan fitoplankton juga menurun.

Pola hubungan fosfat dan fitoplankton di Danau Buyan dapat dilihat pada Gambar 4. Pada setiap stasiun pengambilan sampel menunjukan pola hubungan fosfat dan kelimpahan fitoplankton yang sejalan. Ketika kadar fosfat menurun kelimpahan fitoplankton juga ikut menurun dan sebaliknya. 
Kelimpahan rata - rata fitoplankton di Danau Buyan selama penelitian berkisar antara 1150 1791,67 ind/l. Kelimpahan fitoplankton tertinggi di dapatkan pada stasiun 3. Hal tersebut kemungkinan karena stasiun 3 merupakan tempat keramba ikan sehingga unsur hara yang tersedia melimpah. Fitoplankton memanfakatkan unsur hara nitrat dan fosfat untuk mendukung pertumbuhannya. Kadar nitrat dan fhosfat yang di dapatkan di masing - masih stasiun penelitian cukup tinggi yaitu nilai nitrat 0,895 - 5,545 dan nilai Fosfat berkisar 1,1711-1,259, sehingga fitoplankton memanfaatkan makronurien tersebut untuk mengoptimalkan pertumbuhannya. Hal ini di dukung oleh pendapat Mackenthun (1969), pertumbuhan optimal fitoplankton diperoleh pada kadar nitrat $0,9-3,5 \mathrm{mg} / \mathrm{l}$ dan kadar fhosfat $0,09-$ $1,8 \mathrm{mg} / \mathrm{l}$. tingginya unsur hara tersebut karena adanya kegiatan pertanian di sekitar tepi Danau Buyan sehingga limpasan pupuk pertanian masuk ke badan air yang di bawa oleh aliran air hujan. Sisa - sisa unsure hara dari aktivitas pemupukan, terutama pemupukan urea akan terbawa melalui saluran - saluran irigasi ataupu aliran air hujan.

Selain itu menurut, Wahyuni (2010) faktor faktor yang mempengaruhi kelimpahan fitoplankton adalah ketersediaan nutrien, keberadaan cahaya dikolom perairan dan laju grazing oleh organisme lain selain itu tinggi rendahnya kelimpahan plankton dipengaruhi oleh kondisi parameter fisika kimia perairan antara lain: DO, BOD, COD, Nitrat, Nitrit, fosfat dan Amonia. Fitoplankton adalah makhluk renik yang melayang di permukaan air (Yatim, 2003). Menurut Nontji (2006), fitoplankton merupakan tumbuhan yang seringkali ditemukan di seluruh massa air pada zona eufotik, berukuran mikroskopis dan memiliki klorofil sehingga mampu membentuk zat organik dari zat anorganik melalui fotosintesis. Fitoplankton sebagai organisme autotrof menghasilkan oksigen yang akan dimanfaatkan oleh organisme lain, sehingga fitoplankton mempunyai peranan penting dalam menunjang produktifitas perairan. Keberadaan fitoplankton dapat dilihat berdasarkan kelimpahannya di perairan, yang dipengaruhi oleh parameter lingkungan. Selain sebagai produsen primer, fitoplankton juga sebagai penghasil oksigen terlarut di perairan bagi organisme lain (Kamali, 2004).

Spesies dominan dari masing-masing kelompok fitoplankton yang ditemukan pada keempat stasiun penelitian di Danau Buyan. Pada divisi Chlorophyta ditemukan 2 spesies yang dengan kelimpahan terbesar yaitu dengan rata - rata pada ke empat

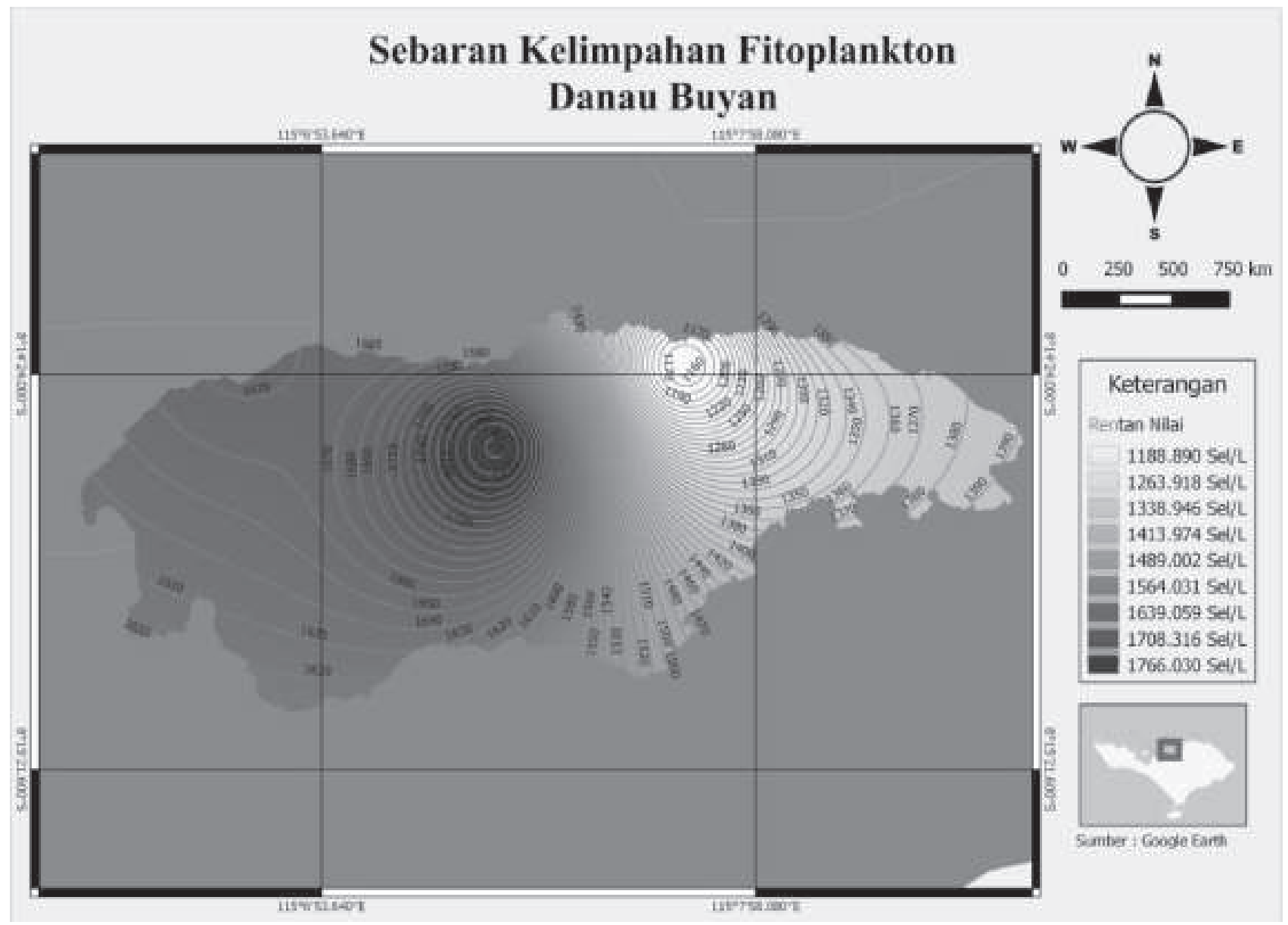

Gambar 5. Peta sebaran kelimpahan fitoplankton di Danau Buyan 
stasiun, Synedra ulna (860.42sel/1) dan Rhizosolenia stolterfothii (22.92 sel/l). dari hasil penelitian oleh Samudra, dkk., (2013) yang di lakukan pada keramba, perairan non keramba dan muara, Synedra ulna merupakan spesies doninan yang di temukan dengan kelimpahan keramba (970 sei/l), perairan non keramba (485 sel/l) dan muara (4365 sel/l). Kelimpahan rata - rata fitoplankton tertinggi di setiap stasiun secara keseluruhan adalalah jenis Synedra ulna. Synedra ulna adalah spesies diatom dominan yang ditemukan pada lapisan atas, spesies ini hadir diduga karena pengaruh akumulasi sedimentasi yang terjadi. Diatom merupakan mikroalga dengan persebaran yang luas dan bersifat kosmopolitan, beberapa diatom dapat digunakan sebagai bioindikator perubahan lingkungan masa lampau, karena sensitifitasnya terhadap kondisi habitatnya dan sifat diatom yang mampu terfosil dengan baik (Hariyati dkk., 2009).

Selain itu pada divisi Chlorophyta juga ditemukan 2 spesies dominan dengan rata - rata kelimpahan tertinggi antara lain Staurastrum paradoxum (102.08 sel/l) dan Chlorococcum humicola (56.25 sel/l). kedua spesies domina tersebut dari hasil penelitian Erdina, dkk., (2010) pada perairan daerah pertanian juga di temukan Staurastrum paradoxum (2,31 sel/l) dan Chlorococcum humicola (6,93 sel/l). sekitaran Danau Buyan juda di kelilingi oleh lahan pertanian sehingga hal ini juga merupakan salah satu factor keberadaan spesies dominan Staurastrum paradoxum dan Chlorococcum humicola pada perairan Danau Buyan.

Spesies yang mendominasi pada divisi Cyanophyta yaitu, Gloeocapsa magma (18.75 sel/ l). dari hasil penelitian Pratiwi (2015) di temukan Gloeocapsa sp. (59 sel/1) di perairan laut malang. Menurut Fachrul, dkk., (2008) Gloeocapsa sp. Juga di temukan di perairan sungai ciliwung Jakarta. Spesies yang dominan pada divisi Chrysophyta yaitu, spesies Melosira granulate (16.67 sel/l). dari hasil penelitian Hariyati, (2009) pada perairan Danau Rawapening Semarang Jawa Tengah di temukan Melosira sp sebanyak 153 sel/l. sedangkan pada 2 divisi Dinophyt dan Pyrrophycophyt tidak ditemukan spesies yang terlalu dominan, namun di temukan spesies Diplopsalis lenticula (2.08 sel /l) dan pada divisi Pyrrophycophyt juga ditemukan spesies Hypnodinium sphaericum (2.08 sel/l). Kelompok dimana ditemukan kelimpahan fitoplankton yang rendah memiliki karakteristik perairan dengan kandungan oksigen terlarut rendah serta nitrat yang rendah. Hal yang sama juga dijumpai pada kelompok yang memiliki kelimpahan fitoplankton yang relatif tinggi, dengan kandungan oksigen terlarut dan nitrat juga ditemukan lebih tinggi. Parameter oksigen terlarut dan nitrat memiliki peranan yang sangat besar dalam membedakan tinggi rendahnya kelimpahan fitoplankton di Danau Buyan. Meskipun demikian parameter lainnya juga ikut berperan bersama-sama tetapi dengan peranan yang relatif lebih kecil dibandingkan dengan peranan parameter DO dan nitrat (Meiriyani, 2013).

Indeks dominansi fitoplankton di Danau Buyan berkisar antara 0,469-0,698. Nilai rata-rata Indeks Dominansi Fitoplankton adalah 0,59. Hal tersebut menunjukan dominansi spesies di Danau Buyan tergolong rendah, karena nilai tersebut mendekati 0 . Nilai indeks dominansi tidak jauh berbeda pada ke empat stasiun, hal ini di sebabkan karena pada seluruh stasiun pengambilan sampel terdapat dominansi satu spesies yaitu Synedra ulna. Dari hasil penelitian yang dilakukan oleh Wahyudiati, (2016) Indek dominansi fitoplankton di Bendungan Telaga Tunjung juga tergolong rendah antara 0,240,38, hal ini juga disebabkan karena terdapat satu spesies dominan yaitu Peridinium sp. Hal ini juga di dukung oleh penelitian yang dilakukan oleh, Jannah (2012) hasil analisis indeks dominansi menunjukkan bahwa secara umum di wilayah estuaria Krueng Aceh tidak didominasi oleh jenis jenis tertentu terlihat dari nilai indeks dominansi yang rendah. Indeks dominansi pada Stasiun 1 adalah 0,016, pada Stasiun 2 adalah 0,045 dan pada Stasiun 3 adalah 0,040. Hal ini diduga karena kondisi lingkungan yang terukur selama penelitian seperti suhu, salinitas dan kecerahan, mendukung pertumbuhan fitoplankton.

Nilai Indeks keanekaragaman di Danau Buyan antara 0.812 - 1.455. Nilai rata - rata indeks keanekaragaman fitoplankton 1,09. Nilai tersebut menunjukan keanekaragaman spesies di Danau Buyan rendah. Menurut, Wahyudiati, (2016) Indeks keanekaragaman dikatakan rendah jika nilainya kurang dari 2,306. Hal ini mengindikasikan perairan tersebut sedang mengalami tekanan ekologi. Nilai indeks keanekaragaman terendah berada di stasiun III dan tertinggi di stasiun IV. Hal tersebut berbanding terbalik dengan indeks dominansi.

Indeks kesamaan di Danau Buyan berkisar antara 0,326 - 0,662. Nilai rata - rata indeks kesamaan fitoplankton adalah 0,47. Nilai ini tergolong sedang, karena lebih dari 0,5. Hal ini menunjukan penyebaran spesies merata dan komonitas fitoplankton dalam kondisi labil. Nilai indeks yang mendekati 1 mempunyai keanekaragaman jenis yang tinggi, sebaliknya jika nilai indeks yang mendekati 0 menunjukkan rendahnya keragaman jenis yang dimiliki oleh suatu komunitas (Odum, 1993).

Eutrofikasi adalah pengkayaan perairan oleh unsur hara, khususnya nitrogen dan fosfat sehingga mengakibatkan pertumbuhan tidak terkontrol dari tumbuhan air. Berdasarkan kandungan unsur haranya, maka perairan dapat dikategorikan menjadi oligotrofik, mesotrofik dan eutrofik. Kesuburan 
perairan merupakan pengayaan air dengan nutrient/ unsur hara berupa bahan anorganik yang dibutuhkan oleh tumbuhan dan mengakibatkan terjadinya peningkatan produktivitas primer perairan (Suprapto, 2014). Kesuburan perairan juga berkaitan dengan kelimpahan fitoplankton. Kelimpahar rata rata fitoplankton yaitu sebesar 1504.17 sel/l. nilai ini menunjukan bahwa kesuburan perairan di Danau Buyan tergolong rendah (oligotrofik). Danau di katakana oligotrofik jika memiliki nilai kelimpahan antara 0 - 2000 sel/l (Handayani, 2009). Menurut Soeprobowati (2010) dari hasil penelitiannya di Danau Rawa Pening termasuk kategori oligotrofik. Hal ini karena kandungan klorofil-a yang terukur merupakan ekspresi dari fitoplankton (produsen primer). Produktivitas primer ditentukan oleh kandungan klorofil-a. Jika di suatu perairan terjadi blooming mikroalga, tentu saja kandungan klorofilnya akan tinggi. Namun, yang terjadi di Danau Rawa Pening, mikroalga kalah bersaing dengan tumbuhan tingkat tinggi sehingga populasinya rendah dan tumbuhan air yang mendominasi. Itulah sebabnya kandungan klorofila di Danau Rawa Pening kurang mengekspresikan status trofik. Hal ini sesuai dengan keadaan Danau Buyan saat penelitian yaitu banyaknya terdapat tanaman air yang merambat di permukaan perairan Danau Buyan.

Selain berdasarkan kelimpahan plankton, status kesuburan perairan juga dapat diketahui dari kadar nitrat. Kadar nitrat rata - rata di Danau Buyan sebesar 2,31 mg/l. hal ini menunjukan tingkat kesuburan Danau Buyan tergolong sedang (mesotrofik). Menurut Wetzel (1983), kadar nitra 0 $1 \mathrm{mg} / \mathrm{l}$ menujukan perairan tersebut tergolong oligotrofik, kadar nitrat $1-5 \mathrm{mg} / \mathrm{l}$ tergolong dalam perairan mesotrofik dan kadar 5-50 mg/l tergolong perairan eutrofik. Hal ini sesuai dengan penelitian yang dilakukan Aisyah (2013) hasil penelitian menunjukkan bahwa kisaran nilai nitrat, fosfat dan klorofil-a pada Bulan Mei dan Juni masing-masing adalah 1,38-2,18 mg/L dan 1,32-2,12 mg/L (eutrofik); 0,013-0,030 mg/L dan 0,012-0,031 mg/L (eutrofik) serta 4,67-7,22 $\mathrm{mg} / \mathrm{L}$ dan 4,71-7,30 $\mathrm{mg} / \mathrm{L}$ (mesotrofik). Berdasarkan kelimpahan plankton dan kadar nitrat, perairan Danau Buyan tergolong kedalam perairan yang memiliki kesuburan sedang (mesotrofik).

\section{SIMPULAN DAN SARAN}

\subsection{Simpulan}

Kegiatan pertanian di sekitar Danau Buyan di lihat dari kandungan nitrat mengakibatkan tingkat eutrofikasi sedang (mesotrofik). Kelimpahan rata rata fitoplankton pada setiap stasiun di Danau Buyan berkisar antara 1150-1791,7 sel/l. Berdasarkan kelimpahan fitoplankton, perairan Danau Buyan tergolong kedalam perairan yang memiliki kesuburan sedang (mesotrofik).

\subsection{Saran}

Perlu adanya pengendalian penggunakan pupuk anorganik disekitar perairan Danau Buyan dan pembersihan tanaman air secara rutin yang di lakukan oleh masyarakat sekitar danau agar tidak menghambat kelimpahan fitoplankton, mengingat fitoplankton merupakan suber makanan ikan.

\section{DAFTAR PUSTAKA}

APHA (American Public Health Association). 1989. Standar Methods for The Examination of Water and Wastewater. American Public Control Federation. 20th edition, Washington DC. American Public Health Asosiation.

Aisyah. 2013. Status Trofik Perairan Rawa Pening Ditinjau Dari Kandungan Unsur Hara Nitrat dan Fosfat Serta Klorofil-a. Pusat Penelitian Pengelolaan Perikanan dan Konservasi Sumberdaya Ikan.

Effendi, H. 2003. Telaah Kualitas Air bagi Pengelola Sumber Daya dan Lingkungan Perairan. Kanisius. Yogyakarta.

Erdina, dkk. 2010. Keanekaragaman dan Kemelimpahan Alga Mikroskopis Pada Daerah Persawahan di Desa Sungai Lumbah Kecamatan Tanalalak Kabupaten Barito Kuala. Jurnal Wahana Bio Volume III.

Fachrul, dkk. 2008. Komposisi dan Model Kemelimpahan Fitoplankton di Perairan Sungai Ciliwung, Jakarta Composition and abundance model of phytoplankton in water of Ciliwung River. Biodiversita. ISSN: 1412-033X Volume 9, Nomor 4 Oktober 2008 Halaman: 296300.JurusanTeknik Lingkungan, Universitas Trisakti.

Handayani, D. 2009. Kelimpahan dan Keanekaragaman Plankton di Perairan Pasang Surut Keramba Blanakan Subang. Progam Studi Biologi. Fakultas Sains dan Teknologi. Universitas Islam Negeri Syarif Hidaya Tullah. Jakarta.

Hariyati, R. Trias, S.W. 2009. Struktur Komunitas Fitoplankton sebagai Bio Indikator Kualitas Perairan Danau Rawapening Kabupaten Semarang Jawa Tengah. Laboratorium Ekologi dan Biosistematika Jurusan Biologi F. MIPA UNDIP. 5 (5) : 55-61.

Jannah., dkk. 2012. Komunitas fitoplankton di daerah estuaria Krueng Aceh, Kota Banda Aceh 
Phytoplankton community in estuary area of Krueng Aceh, Banda Aceh. Depik, 1(3): 189-195 Desember 2012 ISSN 2089-7790 189. Jurusan Budidaya Perairan, Koordinatorat Kelautan dan Perikanan, Universitas Syiah Kuala. Banda Aceh 23111, Provinsi Aceh.

Kamali, Dzikrulloh. 2004. Kelimpahan Fitoplankton Pada Keramba Jaring Apung Di Teluk Hurun Lampung. Skripsi. IPB, Bogor.

Krebs, C.J., 1985. Ecology (The experimental Analysis of Distribution and Abundance). Harper \& Row Publisher. New York.

Nontji, A. 2006. Tiada Kehidupan Di Bumi Tanpa Keberadaan Plankton. Lembaga Ilmu Pengetahuan Indonesia Pusat Penelitian Oseanologi, Jakarta. 248p

Mackenthum,K.M. 1969. The Practice of Water Pollution Biology. United States Departement of Interior, Federal Water Pollution Control Administration Division of Technical Support.

Michael, P. 1994. Metode Ekologi Untuk Penyelidikan Lapangan dan Laboratorium. UI press, Jakarta.

Meiriyani , dkk. 2011. Komposisi dan Sebaran Fitoplankton di Perairan Muara Sungai Way Belau, Bandar Lampung . Putri Program Studi Ilmu Kelautan FMIPA Universitas Sriwijaya. Journal 03 (2011) 69-77.

Odum, E.P., 1971. Dasar-dasar Ekologi. Gajah Mada University Press.
Pratiwi, E.D. 2015. Hubungan Kelimpahan Plankton Terhadap Air di Perairan Malang Rapat Kabupaten Bintan Provinsi Kepulauan Riau. Mahasiswa Jurusan Ilmu Kelautan, FIKP UMRAH.

Samudra, dkk. 2013. Komposisi, Kemelimpahan dan Keanekaragaman Fitoplankton Danau Rawa Pening Kabupaten Semarang. BIOMA. ISSN: 1410-8801 Vol. 15, No. 1, Hal. 6-13. Program Studi Magister Biologi, Universitas Diponegoro.

Suprapto, dkk. 2014. Aquatic Productivity Analysis based on The Relationship between Physical and Chemical of Benthic Sediment with NO3 and PO4 in the Estuarine of Tuntang River Available online at Indonesian Journal of Fisheries Science and Technology (IJFST). Saintek Perikanan (Indonesian Journal of Fisheries Science and Technology), ISSN : 1858-4748 56.

Wahyudiati, W.D. 2016. Strutur Komonitas Plankton dan Kualitas Perairan Di Bendungan Telaga Tunjung Tabanan. Program Studi Kelautan. Universitas Udayan Bukit Jimbaran Bali.

Wetzel, R.G. 1983. Limnology $2^{\text {nd }}$ Edition. Saunders College Publishing. Philadephia.

Yamaji, I. 1976. Illustration of Marine Plankton. Japan: Hoikusha Publishing Co Ltd. 371p.

Yatim, W. 2003. Biologi Medern Biologi Sel.Tarsito. Bandung. 